\title{
REGIONAL LABOUR MARKET INTEGRATION IN ENGLAND AND WALES, 1850-1913
}

\author{
George R. Boyer and Timothy J. Hatton
}

It often is maintained that as economies mature, their labour markets become better integrated both geographically and between the rural and urban sectors. Declining transport costs, improved information flows, and declining institutional impediments to migration lead to an increase in labour mobility. As a result, regionally or locally segmented labour markets become increasingly integrated at the national or even the international level.

This chapter examines the integration of labour markets within the rural and urban sectors of England and Wales during the second half of the nineteenth century. Although there is a large literature on internal migration and emigration in Victorian Britain, historians typically have focused on the direction and causes of migration rather than on its consequences for the labour market. ${ }^{1}$ Broadly speaking, the literature has found that workers did indeed migrate towards better wage-earning opportunities, that most moves were short-distance moves, and that once certain patterns of migration were established they often persisted. The studies leave the strong impression, if only implicitly, that although there was considerable migration, opportunities for arbitrage were not fully exploited. However, analyses of the pattern and extent of migration movements shed little light on the issue of integration. Markets could be perfectly integrated but exhibit little migration or they could exhibit high rates of migration but be poorly integrated.

A better measure of labour market integration can be obtained by examining wage rates. There is a large literature on the history of wages during the nineteenth century. However, with the exception of Arthur Bowley (1898, 1900a, 1900b, 1901), A. Wilson Fox (1903), and most importantly E.H. Hunt (1973, 1986), historians have not examined the changes over time in local or regional variations in wages within occupations.

This chapter extends the work of Bowley, Fox, and Hunt, by offering several tests for the degree of labour market integration and its trend from 1850 to 1913 . We construct annual regional wage series for agricultural labourers and carpenters, and use these new wage series to test for regional 
wage convergence and to estimate structural models to assess the degree of labour market integratipn between regions.

\section{PREVIOUS STUDIES OF LABOUR MARKET INTEGRATION}

E.H. Hunt's (1973, 1986) recent conclusion that the British labour market became better integrated from 1850 to 1914 represents somewhat of a break from the historical literature. The few contemporaries and historians who previously had examined wage variations within occupations before 1914 generally were struck by the apparent lack of labour market integration. The existence of large local and regional wage differentials was often commented on, especially in studies of the agricultural labour market. We begin by reviewing the conclusions reached by these earlier studies of labour market integration.

Perhaps the best known comment on labour market integration in nineteenth century Britain was made by the agricultural journalist James Caird (1852: 517), who concluded from his tour of rural England in 1850-1 that a 'marked inequality in wages . . . bisects the kingdom by unmistakable lines into two great geographical divisions', the high-wage north and the lowwage south. Caird blamed the regional wage differential on low labour mobility caused by the Poor Law and the Settlement Law (1852: 517). Frederick Purdy (1861), the author of a study of agricultural labourers' wages in 1860, reached a conclusion similar to that of Caird. He wrote that 'no commodity in this country presents so great a variation in price, at one time, as agricultural labour. ... A labourer's wages in Dorset, or Devon, are barely half the sum given for similar services in the northern parts of England' (1861: 344). Purdy (1861: 345) also noted that 'considerable differences in wages obtain in small areas'. He cited several instances in which wages varied by $2 \mathrm{~s}$. to $4 \mathrm{~s}$. across parishes within a Poor Law union.

Thirty years later, Joseph Ashby and Bolton King (1893), the authors of a study of the living conditions of agricultural labourers in south Warwickshire in 1892, also found significant local variations in labourers' wages. They wrote that 'in one village the rate of wages has been throughout, from 1872 at least, $2 \mathrm{~s}$. below the rate in the surrounding villages. It is not at all uncommon to find a difference of Is. $6 \mathrm{~d}$. to $2 \mathrm{~s}$. in adjacent villages' (1893: 5). They attributed these differences partly to differences in the demand for and supply of labour, and partly to custom (1893: 5-8).

Economic historian J.H. Clapham, discussing the extent of wage variations in agriculture in 1902, wrote that:

Variations in earnings from county to county remained astonishingly great. The broad divisions corresponded roughly with differences in labour efficiency. . . . Yet differences in efficiency can hardly explain such gaps as those between the 14s. $6 \mathrm{~d}$. of Oxfordshire, . . the 16s. $4 \mathrm{~d}$. 


\section{GEORGE R. BOYER \& TIMOTHY J. HATTON}

of Buckingham, the 16s. lid. of Essex and the 20s. of Surrey. Surrey no doubt runs into London; but so does Essex, and the Buckingham and Oxford boundaries are not very far away. Some explanation connected with mobility is more probable.

(Clapham 1938: 97-8)

The literature on wage variations within urban occupations is much smaller than that on agriculture. The first person seriously to examine wage variations across cities was F.W. Lawrence (1899). He found (1899: 18) that 'marked changes [in wage rates in the same trade] are noticeable as we pass from one part of the country to another'. Rather than view these regional wage differentials as evidence of labour immobility, Lawrence (1899: 52) concluded that they largely were a result of regional differences in the 'character of the people. ... So that where the higher wages are paid they are merely a higher price for a better article.'

J. W.F. Rowe (1928: 67) concluded from his study of wages in the building trades that, before 1914, 'even amongst towns of the same size in the same county, or group of counties, the variations [in wage rates] were appreciable'. He maintained that these variations could only partly be explained by differences in the cost of living or in the demand for labour, and attributed the remaining differentials to 'that unsatisfactory agency, custom' (1926: 68). Concerning the trend in regional integration, Rowe (1928: 70) concluded that the 'variations in wage rates [in 1914] presented a picture hardly more uniform or symmetrical than that of 1893'.

E.H. Hunt $(1973,1986)$ is the only individual to examine explicitly the trends in labour market integration in nineteenth century Britain. His analysis focused on wage rates of agricultural labourers in 1867-70, 1898, and 1907, and, to a lesser degree, wage rates of carpenters and building labourers in 1886 and 1906. In his 1973 book, Hunt divided Britain into thirteen regions and examined trends in the regional wage structure, whereas in his 1986 article he considered agricultural wages at the county level and carpenters' wages in six cities.

Hunt (1973) concluded that the regional wage structure was relatively stable over the period 1850 to 1914 . He wrote that

in broad terms there were two high-wage areas in 1850: the London area; and the counties of the north of England together with parts of the Midlands as far south as Birmingham. In 1914 the position was similar except that these two areas had been joined by South Wales and much of southern and central Scotland.

(Hunt 1973: 4)

The only other significant change in the regional wage structure was that the rural southeast of England replaced the southwest as the lowest wage region in Britain (Hunt 1973: 17, 64). 


\section{REGIONAL LABOUR MARKET INTEGRATION}

Hunt (1973: 58) maintained that 'there is one generalization which may be made with confidence about most [wage] differentials - they were less wide at the end of the period than in 1850'. To determine the trend in regional labour market integration, Hunt calculated the coefficient of variation of agricultural labourers' weekly earnings across eighty-six British counties in 1867-70, 1898, and 1907, and of bricklayers' weekly wages across twentyone English and Welsh towns in 1886, 1900, and 1913. ${ }^{2}$ For agricultural labourers, the coefficient of variation declined from 0.14 in 1867-70 to 0.10 in 1898 , and then to 0.09 in 1907 . For bricklayers, it declined from 0.145 in 1886 to 0.107 in 1906 , and then remained roughly constant at 0.108 in 1913 (1973: 59). Hunt (1973: 60) concluded that 'what is remarkable about [the wage] differentials is not that they were reduced but that they persisted so tenaciously'. He maintained that this was not caused by labour immobility. Rather, 'between 1850 and 1914 there were strong forces working to reinforce the existing wage differentials, forces so strong that it would be rash to assume that the slow erosion of regional differentials necessarily implies a high degree of immobility' (1973: 242).

Hunt's finding that regional wage variations declined from 1850 to 1914 is suspect, for two reasons. First, it is based on an examination of wage rates of agricultural labourers and bricklayers at only three points in time. For the purposes of establishing whether there was a discernible downward trend in the variation of wages it clearly would be desirable to examine annual time series of wages rather than rely on three benchmark years. Second, Hunt's earnings data for agricultural labourers are drawn from a separate source for each benchmark year, which raises issues of comparability. The problem is made worse by Hunt's comparison of estimated weekly earnings rather than cash wages. The earnings data include estimates of the average weekly value of extra wages at harvest time, occasional piece work, and perquisites ranging from a rent-free cottage to beer or cider at harvest time. Although the value of these items should be included in the total wage, it is not clear that the items were adequately measured in the surveys or that when included they were appropriately valued. Most importantly, there is no reason to believe that the valuation of the items was comparable across the three surveys. Because of the problems associated with using estimates of agricultural labourers' earnings, we focus on weekly cash wage rates, although we recognize that this is not the ideal measure.

Like the previous studies of labour market integration, in this chapter we focus on regional variations in wages in two occupations: agriculture and the building trades. Wage rates in these occupations generally are considered to be representative of rural and urban unskilled and skilled wage rates. Bowley (1914: 617) maintained that 'agricultural wages are in close sympathy with wages that can be obtained for unskilled labour in the same neighbourhood'. Similarly, Hunt (1973:4) contended that 'farm labourers' earnings are probably the most useful single guide to wage levels in different parts of Britain'. 
Bowley (1900a: 59, 63) used bricklayers' and carpenters' wages as a proxy for general wage trends. Hunt (1986: 962) maintained that

in most respects the wages of carpenters and other building workers can be regarded as a reasonably reliable guide to town wages. There were building workers in every town; the nature of their work did not vary much from place to place, nor was it much affected by technical change; and within towns a single rate of pay prevailed in each of the building occupations.

We use two previously neglected data sources to construct annual time series of average regional wage rates for agricultural labourers from 1855 to 1903 and for carpenters from 1865 to 1913. Agricultural wage data were obtained from the Second Report ... on the Wages, Earnings, and Conditions of Employment of Agricultural Labourers in the United Kingdom (1905a), written by Wilson Fox for the Board of Trade. Appendix V reports annual observations of 'weekly cash wages paid to ordinary agricultural labourers' on individual farms scattered throughout England and Wales for the years 1850 to 1904. Continuous wage series for the period 1855-1903 are available for seventy-nine farms. Carpenters' wage data were obtained from an unpublished Board of Trade report on Rates of Wages and Hours of Labour in Various Industries in the United Kingdom (1908a), supplemented for the years 1907-13 by the Abstracts of Labour Statistics (1907-1912-13) and the Reports on Standard Time Rates of Wages (1909-14) published by the Labour Department of the Board of Trade. Continuous wage series for the period 1865 to 1913 are available for twenty-nine towns. The published wage rates typically are the standard trade union rates, which might create questions of representativeness if non-unionists worked at lower rates. However, Rowe (1928: 65) maintained that even before the First World War 'in each town or country district the building operatives of each grade were almost invariably paid the trade union standard rates of wages'. 3

We grouped the farms and towns in our samples into six regions: the north, midlands, east, south, southwest, and Wales. The regions correspond broadly to the regional breakdown used by Hunt (1973), although we distinguish fewer regions. ${ }^{4}$ For each region we construct time series of the average weekly wage of agricultural labourers and carpenters. For agricultural labourers the regional wage is calculated as the simple average of the wages of the farms in the region, while for carpenters the regional wage is calculated as a weighted average of the wages of the towns in the region; the weights used were the population of the city in 1891. Because most of the towns for which we have carpenters' wage data are in the industrial north and midlands, the other regions are represented by very few towns. For Wales we have wage data for Cardiff and Newport, for the southwest we have data for Bristol and Plymouth, and for the south and east we have data only for London. 


\section{MODELLING WAGE RATES AND TESTING FOR MARKET INTEGRATION}

In this chapter we pursue a number of different approaches for examining labour market integration. These go somewhat beyond the methods used in the existing literature on regional labour markets in Britain. The usual approach, reflected in the discussion above, assumes that the wage, suitably adjusted, should be the same in each location. In principle, this involves adjusting for differences in the cost of living, non-cash payments, hours, working conditions, and wage-earning opportunities for other family members, as well as measuring (and appropriately valuing) all the non-wage characteristics of location. Any gap remaining is a measure of market failure. This approach has been used formally in recent studies of late nineteenth century US wage differentials between urban centres (Rosenbloom 1990) and between the urban and rural sectors in a single region (Hatton and Williamson 1992). It is also one of the principal methods used by Hunt (1973) in his analysis of late nineteenth century Britain.

There are several drawbacks with this approach as a test or measure of labour market integration. First, we cannot expect to measure exactly all the advantages and disadvantages of location. Hence, we would probably observe some wage differential even in the unlikely event that the labour market was perfectly arbitraged. If, as is more likely, we only observe cash wages, there is no way of knowing whether a given wage gap represents equilibrium or disequilibrium. Second, even if we could measure and correctly value all the wage and non-wage attributes of a region, we have no criterion to determine how large the gap could be before we conclude that labour markets were not integrated. To demand that the wage gap be equal to zero, requiring as it does that labour markets are instantly arbitraged, is surely too harsh a test. Third, under imperfect arbitrage, shocks to labour supply and demand are likely to drive wage differentials away from equilibrium. Cross-sectional comparisons will not, in general, distinguish between the impact of shocks to labour demand or supply and lack of labour market mobility.

One approach to testing for changes in the degree of market integration is to search for trends over time in a measure of the dispersion of wage rates, such as the coefficient of variation. This technique has been used by Rothenberg (1988), who finds that farm wage rates within the state of Massachusetts converged during the first half of the nineteenth century. She interprets this as evidence that a state-wide labour market had emerged by 1850. For this to be the case, it must be assumed that the measured wage effectively summarizes the advantages or disadvantages of each location. Otherwise a narrowing of the 'true' wage differentials could be accompanied by a divergence of the measured differentials or vice versa. However, this approach has the advantage that, provided a sufficiently long time series of 
the chosen measure of dispersion is available, the underlying trend can be discerned even in the presence of temporary shocks. ${ }^{5}$ Unfortunately, the analysis of trends in wage dispersion says little about the degree of integration of labour markets. An absence of any distinct trend in the measure of dispersion could be consistent with very well integrated markets or verypoorly integrated markets. For these reasons it is worth pursuing time series methods.

Several different time series methods have been used to determine the degree of integration between two markets. One method calculates the correlation coefficient of wage changes between the two labour markets. The higher the correlation coefficient, the more closely integrated the two markets are assumed to be. ${ }^{6}$ However, this test for integration is flawed, because it does not enable one to distinguish between a strong tendency for instantaneous arbitrage and common shocks to labour demand or supply. A high correlation in changes does not necessarily mean that the two wage series move together in levels in the long run as market integration implies.

An alternative method for determining the extent of integration between two labour markets consists of testing for a unit root in the ratio of the two wage series. A number of widely used unit root tests have been developed by Engle and Granger (1987). Although these tests enable one to examine the long-run integration of labour markets, they also have drawbacks. In empirical applications, the tests are often found to be weak against the null hypothesis of no cointegration (Engle and Granger 1987: 269).

A major disadvantage of simple correlations or cointegration (unit root) tests is that they generally are not based on a structural model of the forces that determine the relationship between two wage rates. We develop a structural model based on labour demand and supply in two labour markets linked together by migration. The model is developed in full in the Appendix and will only be sketched out here.

The chief force towards the convergence of wages in two labour markets is migration. Where there are only two labour markets / and;, migration from / to; can be represented as follows:

$$
\left.\left.\mathrm{m}^{\wedge} \mathrm{ctlog} \mathrm{fW} / \mathrm{Wi}\right),-!-*\right]
$$

where mij is the rate of net migration from $i$ to; (negative for migration from ; to $i$ ), $c$ is a parameter measuring the responsiveness of migration to a given wage differential, and $k$ represents the non-wage advantages of market $i$ relative to market;. The rate of migration depends on the wage ratio and on the mobility parameter, $c$. The greater is the wage ratio, and therefore the incentive to move, the greater will be the flow of migrants. The parameter $c$ determines the degree of integration between the two labour markets. As $c$ approaches infinity labour becomes perfectly mobile and the two labour markets are perfectly integrated. If $c$ was zero then the markets would not be integrated at all. 


\section{REGIONAL LABOUR MARKET INTEGRATION}

The migration relation which links the labour markets together has implications for the wage yatio. If $\log \left(\mathrm{W}, / \mathrm{W}_{\mathrm{z}}\right), \mathrm{i}>k$ then labour would flow from $i$ to; (assuming $c>0$ ). The increase in labour supply in market; would tend to lower $W j$ while the fall in labour supply in $i$ would raise $\mathrm{W}$,- The ratio $\log (\mathrm{W}, 7 \mathrm{~W},-)$ would, over time, tend to fall and this process would continue (at a decreasing rate) until $\log \left(\mathrm{W}_{/} / \mathrm{W}_{\mathrm{z}}\right)=k$. Hence, there would be a long-run tendency towards the wage ratio $W / W i=e^{k}$ and if $k=0$ then in the long run $W j / W i:=1$.

In the Appendix we have used a variant of this migration equation which allows for migration to and from third markets. We also introduce a simple model of labour demand in each market which allows us to eliminate migration and to express the relation between the two markets in terms of the wage alone. This yields the following relationship which we can estimate:

$$
\operatorname{Alog} W_{l t}=d_{0}+d_{t} \operatorname{Alog} W_{l t}+d_{2} \log (W i / W j)_{-},+v_{t}
$$

The parameter $d \wedge$ reflects the degree to which there are common forces affecting both labour markets while $d_{2}$ is a measure of the degree of integration of the two markets. The size of $d_{2}$ is determined by the mobility parameter in the migration equation; if the mobility parameter was equal to zero then $d_{2}$ also would be equal to zero.

This type of model is sometimes called an error correction model. The two wage rates are related in changes but the error correction term $d_{2} \log (\mathrm{W} / /$ $W j)_{t}-\mathrm{j}$ prevents them from wandering apart over time in levels (provided $d_{2}$ is negative). ${ }^{7}$ If we imagine a long-run stationary equilibrium where $\mathrm{Alog}^{\wedge}$ $=A \log W j_{t}=v_{t}=0$, then $\log \left(\mathrm{WW}_{;}\right)_{\mathrm{t}-1}=-d_{Q} / d_{2}$. That is, $-d_{0} / d_{2}$ represents the long-run equilibrium wage ratio.

We now turn to the empirical analysis of regional labour market integration. We begin in the next section by testing for trends in wage dispersion, and then move on in the following section to time series tests for market integration.

\section{COEFFICIENT OF VARIATION TESTS FOR MARKET INTEGRATION}

E.H. Hunt's (1973: 58-9) conclusion that labour markets became better integrated from 1850 to 1914 was based on estimates of the coefficient of variation of wages for agricultural labourers and bricklayers at a few points in time. In this section we re-examine the trend in labour market integration for these two occupations, using the same methodology as Hunt. We construct annual wage series for seventy-nine farms from 1855 to 1903 and for carpenters in twenty-nine towns from 1865 to 1913, and then calculate the annual coefficient of variation of wages for both occupations.

Our analysis offers a more accurate measure of the trend in labour market 
integration, for three reasons. First, an analysis based on an annual time series of wages is preferable to one based on three benchmark years. Second, Hunt's agricultural wage data are drawn from a different source for each benchmark year, while our wage data are for the same set of farms for each year. Thus, Hunt's data might not be comparable across years, while our data almost certainly are. Third, Hunt's estimates of the coefficient of variation are based on nominal wage data. The use of nominal wages is valid for the analysis of the agricultural labour market but not for the analysis of urban occupations. Hunt (1973: 80-7) examined differences in rents and food and fuel prices across rural Britain, and concluded that 'the cost of living of rural workers did not vary significantly in different parts of the country: differences in real wages paralleled differences in money wages'. ${ }^{8}$ We agree with his conclusion and therefore also use nominal wages in agriculture.

On the other hand, there were significant differences in the cost of living across English towns. A 1908(b) Board of Trade Enquiry into Working Class Rents, Housing and Retail Prices estimated the cost of housing, food, and fuel for working-class families in seventy-seven English and Welsh towns in October, 1905. The study found that, although the cost of living differed by less than 10 per cent among the majority of cities there were outliers, the most important of which was London, whose cost of living was significantly higher than that of most other cities. ${ }^{9}$ To take account of these differences in the cost of living, we deflated the nominal wage of carpenters in each of our twenty-nine towns using the Board of Trade's cost of living index for 1905. Because town-level cost of living estimates do not exist for any earlier year, we were forced to assume that the differences in the cost of living across towns in 1905 held for the entire period 1865-1913.

To determine whether labour markets became more integrated over time, for both occupations we regressed the time series of coefficients of variation on a constant and a time trend (Table 5.1). If there was wage convergence over the period the coefficient of the time trend will be negative and significantly different from zero.

Consider first the regressions for agricultural labourers' wages in part (A) of Table 5.1. The dependent variable in equation (1) is the coefficient of variation of wages for the seventy-nine farms. The regression results show that the coefficient on the time trend is positive and significantly different from zero. Its magnitude suggests that the coefficient of variation increased by 0.023 from 1855 to 1903 . Our results therefore do not support Hunt's conclusion that the variation in agricultural wages declined during the late nineteenth century. ${ }^{10}$ Rather, they suggest that wage dispersion increased from 1855 to 1903 .

The upward trend in the coefficient of variation might have been the result of either increasing inter-regional wage variation or increasing intra-regional wage variation or both. To determine whether intra-regional wage variation 


\section{REGIONAL LABOUR MARKET INTEGRATION}

Table 5.1 Regressions of coefficients of variation of wages on a time trend

Sample $\quad$ Constant Time/100 $R^{2}$ Mean

(A) Agricultural labourers (1855-1903)

(1) All farms

(2) Intra-regional

$(0.003)$

0.046

0.37

0.167

$(0.009)$

0.006

0.02

0.117

(3) Inter-regional

(0.002)

$(0.006)$

$0.099 \quad 0.063$

(0.004)

$(0.011)$

0.39

0.118

(B) Carpenters (1867-1913)

(4) Nominal wage:

0.100

$-0.087$

(0.007)

29 towns

$(0.002)$

$-0.139$

(0.012)

(0.004)

$-0.079$

(0.008)

(0.003)

$-0.094$

0.083
$(0.003)$

(0.010)

$\begin{array}{ll}0.78 & 0.073 \\ 0.75 & 0.070 \\ 0.68 & 0.087 \\ 0.65 & 0.054\end{array}$

(7) Real wage:

0.65

0.054

Note: Standard errors are in parentheses.

increased over time we grouped the seventy-nine farms into six regions, calculated the coefficient of variation for each region, and then calculated the weighted average (by number of farms) of the coefficients of variation of the regions. The resulting series provides a measure of the average intra-regional wage variation for the six regions. In equation (2) we regress this series on a constant and a time trend. The coefficient on the time trend is positive but not significantly different from zero, suggesting that, on average, intraregional wage variation did not increase from 1855 to 1903.

To examine the trend in inter-regional wage variations, we calculated regional average wages, then calculated the coefficient of variation of wages across the six regions and regressed it on a time trend. Equation (3) shows a significant trend towards increasing inter-regional wage dispersion. Together, equations (2) and (3) reveal that the increase in the coefficient of variation of agricultural wages from 1855 to 1903 was caused almost completely by increases in wage variations across regions.

The above results suggest that the agricultural labour market was regionally segmented in the late nineteenth century. However, the increasing regional wage differentials might have occurred despite a high degree of inter-regional labour mobility, if the 'strong forces working to reinforce existing wage differentials' noted by Hunt (1973: 242) could not be overcome even by relatively high migration rates. Unfortunately, we cannot distinguish between these two possibilities by looking at trends in the coefficient of variation.

Part (B) of Table 5.1 analyses carpenters' wages. It is generally maintained 
that the labour markets for skilled occupations were better integrated than those for unskilled occupations, because of the higher mobility of skilled workers. According to Hunt (1981: 155), 'urban skilled workers were . . . better educated, better informed, and more likely to move over long distances. Their trade unions, in particular, were an important source of market information.' Table 5.1 supports this hypothesis; the mean level of the coefficient of variation of carpenters' wages across twenty-nine towns was approximately one-half of the mean level of the coefficient of variation of labourers' wages across seventy-nine farms.

The regressions to examine trends in the coefficient of variation of carpenters' wages were run using both nominal and real wages. Because wage data are available for only a small number of towns within certain regions, we were able to estimate only the trends in overall and inter-regional wage variations. The variation in nominal and real carpenters' wages declined sharply over time both at the town and at the regional level. The coefficients on the time trend in equations (6) and (7) suggest that at the town level the coefficient of variation of real wages declined by 0.037 from 1867 to 1913; at the regional level by 0.044 . In sum, the labour market for carpenters became significantly better integrated in the half century before the First World War.

In this section we have examined changes over time in labour market integration for farm labourers and carpenters by statistically testing for trends in the coefficient of variation of wages. Despite using the same measure of labour market integration that Hunt used, we have reached different conclusions than he did. Regional wage differentials for carpenters declined in the late nineteenth century, but regional differentials for agricultural labourers increased. This result raises several questions about the extent of regional labour market integration, questions that cannot be answered by the analysis of trends in the coefficient of variation. We now turn to time series models of market integration in order to determine the degree of labour market integration between individual regions.

\section{TIME SERIES TESTS FOR REGIONAL INTEGRATION}

In this section we examine the time series relationships between pairs of regions for agricultural labourers' and carpenters' wage rates, to see which regional labour markets were most and which were least integrated with the others. In order to allow for changes over time in the equilibrium wage ratio for each pair of regions, we introduce time trends in the error correction model. We first examine the agricultural wage rates.

Figures 5.1 and 5.2 present the average weekly wage rate of agricultural labourers for each region from 1855 to 1903 . In the north, midlands, and south, wages increased sharply from the late 1850 s to the mid-1870s, then declined slightly in the late 1870 s to a plateau that was maintained from 


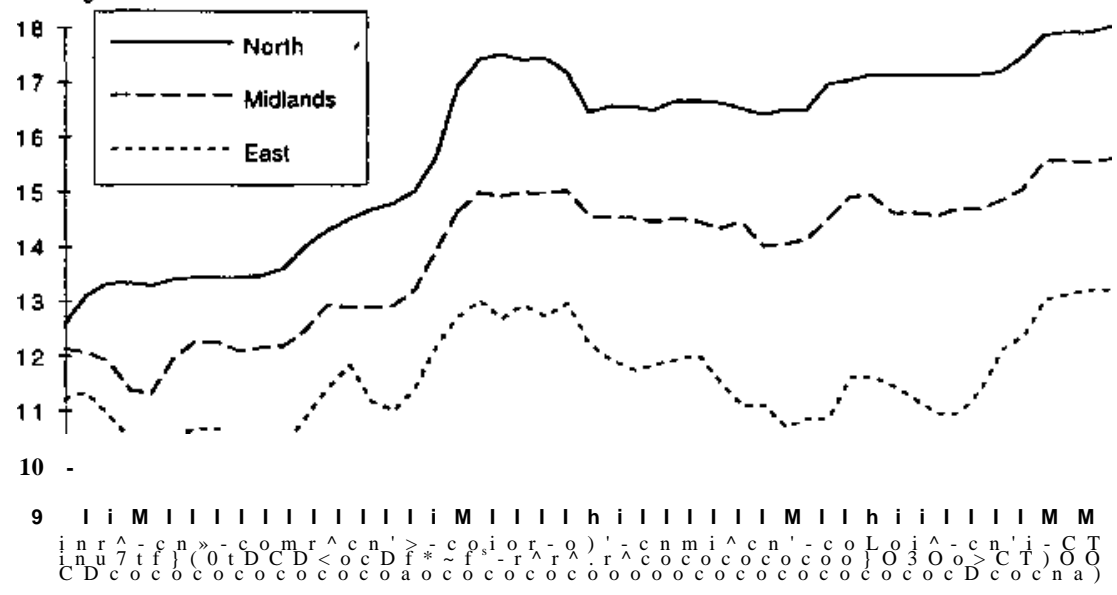

Figure 5.1 Agricultural wages: north, midlands, and east

Source: See text

about 1880 to the late 1890 s, and then increased again around 1900. The wage series for the east follows a somewhat similar path from 1855 to 1880 , although it is much more volatile than the other series. Wages declined during the 1880s, and then increased sharply after 1896. By contrast, the southwest experienced a slow and steady increase in wages with few distinct fluctuations. As in the other regions, wages maintained a plateau in the $1880 \mathrm{~s}$ and increased sharply around 1900. Finally, the wage series for Wales followed a pattern similar to that of the southwest, but with fluctuations in the 1860 s and 1870 s similar to the midlands and the south.

The results obtained from estimating the error correction model for the fifteen pairs of regions are presented in Table 5.2. In each case the coefficient on the $A \log W_{\text {; }}$ term $\{d \backslash$ in equation (5.2) is positive and significantly different from zero at the 5 per cent level. This suggests that common shocks arising from changes in labour supply or demand were important in agricultural labour markets. It is likely that these arose chiefly on the demand side due to fluctuations in agricultural prices and variations in weather conditions. However, there is little evidence that the mainly arable areas of the midlands, south, and east show higher short-run correlations and larger coefficients between them than they do with the more predominantly pastoral areas. ${ }^{11}$

A negative and statistically significant coefficient on the $\log (\mathrm{W}, 7 \mathrm{~W},)_{\mathrm{r}}-\mathrm{i}$ term $\left(d_{2}\right.$ in equation (5.2)) is evidence of convergence to a long run equilibrium wage ratio. The coefficient is negative in each of the regional-pair regressions in Table 5.2. However, seven of the fifteen coefficients are not 
Figure 5.2 Agricultural wages: south, southwest, and Wales

Source: See text

significantly different from zero, suggesting that the equilibrating supplyside forces were weak. The regional pairs exhibiting the strongest evidence of integration are: the midlands and south, north and midlands, north and south, Wales and south, and midlands and Wales. Wales was integrated with every region except the north, while the south, north, and midlands each were integrated with three of the five other regions. All but one of the insignificant coefficients were associated with regressions involving either the southwest or the east. The results suggest that the southwest was integrated only with Wales. Oddly, the east was integrated with the distant north and Wales, but not with the midlands, south, or southwest.

The rate of adjustment of the wage in region / to a shock to the equilibrium wage ratio, holding $W j$ fixed, can be estimated from the coefficient on the $\log (\mathrm{W}: / \mathrm{W},)_{\mathrm{f}} !$ term, $d_{2}$. The predicted lag between an initial shock and the return to equilibrium is equal to $(1-\mathrm{c} / 2)^{/ \wedge} 2-\mathrm{I}^{\mathrm{ntn}}{ }^{\mathrm{n}}$ regressions in Table 5.2 the lag varies from one year and 1.4 years for the midlands/south and north/midlands pairs to 7.3 years and 8.1 years for the Wales/east and north/east pairs.

Before considering the implications of these results we turn to the carpenters' wage rates for comparison. Figures 5.3 and 5.4 present the average weekly wage rate of carpenters for each region from 1864 to 1913. It should be recalled that the south and east are represented only by London. To take account of differences in living costs across cities the series have been adjusted using the Board of Trade's relative cost of living index for 1905. As was observed for the agricultural wage rates, there is a strong similarity in 


\section{REGIONAL LABOUR MARKET INTEGRATION}

Table 5.2 Error correction model for agricultural wages, 1856-1903

\begin{tabular}{|c|c|c|c|c|c|c|}
\hline Region $i, j$ & Const'. & Time $/ 100$ & $M o g W_{j t}$ & logfWywy,-, & $R^{2}$ & $D W$ \\
\hline \multirow[t]{2}{*}{ North, Midlands } & 0.05 & 0.02 & 0.63 & -0.41 & 0.61 & 1.22 \\
\hline & $(0.01)$ & $(0.02)$ & $(0.09)$ & $(0.09)$ & & \\
\hline \multirow[t]{2}{*}{ North, Wales } & 0.04 & -0.03 & 0.50 & -0.15 & 0.27 & 1.39 \\
\hline & $(0.02)$ & $(0.02)$ & $(0.13)$ & $(0.10)$ & & \\
\hline \multirow[t]{2}{*}{ North, Southwest } & 0.04 & -0.03 & 0.78 & -0.09 & 0.29 & 1.07 \\
\hline & $(0.02)$ & $(0.02)$ & $(0.21)$ & $(0.06)$ & & \\
\hline \multirow[t]{2}{*}{ North, South } & 0.08 & 0.03 & 0.65 & -0.32 & 0.63 & 1.46 \\
\hline & $(0.02)$ & $(0.02)$ & $(0.08)$ & $(0.09)$ & & \\
\hline \multirow[t]{2}{*}{ North, East } & 0.04 & 0.02 & 0.28 & -0.11 & 0.37 & 1.45 \\
\hline & $(0.01)$ & $(0.02)$ & $(0.07)$ & $(0.04)$ & & \\
\hline \multirow[t]{2}{*}{ Midlands, Wales } & 0.02 & -0.06 & 0.56 & -0.29 & 0.22 & 1.34 \\
\hline & $(0.01)$ & $(0.03)$ & $(0.16)$ & $(0.11)$ & & \\
\hline \multirow{2}{*}{$\begin{array}{l}\text { Midlands, } \\
\text { Southwest }\end{array}$} & 0.03 & -0.03 & 0.98 & -0.12 & 0.30 & 1.48 \\
\hline & $(0.02)$ & $(0.02)$ & $(0.24)$ & $(0.07)$ & & \\
\hline \multirow[t]{2}{*}{ Midlands, South } & 0.05 & 0.03 & 0.83 & -0.51 & 0.60 & 1.73 \\
\hline & $(0.01)$ & $(0.02)$ & $(0.10)$ & $(0.13)$ & & \\
\hline \multirow[t]{2}{*}{ Midlands, East } & 0.01 & 0.01 & 0.43 & -0.06 & 0.48 & 1.06 \\
\hline & $(0.01)$ & $(0.02)$ & $(0.07)$ & $(0.06)$ & & \\
\hline \multirow[t]{2}{*}{ Wales, Southwest } & 0.05 & -0.02 & 0.84 & -0.23 & 0.32 & 1.98 \\
\hline & $(0.02)$ & $(0.02)$ & $(0.21)$ & $(0.09)$ & & \\
\hline \multirow[t]{2}{*}{ Wales, South } & 0.02 & 0.07 & 0.46 & -0.31 & 0.21 & 1.42 \\
\hline & $(0.01)$ & $(0.03)$ & $(0.11)$ & $(0.09)$ & & \\
\hline \multirow[t]{2}{*}{ Wales, East } & 0.02 & 0.04 & 0.25 & -0.12 & 0.29 & 2.17 \\
\hline & $(0.01)$ & $(0.03)$ & $(0.07)$ & $(0.05)$ & & \\
\hline \multirow[t]{2}{*}{ Southwest, South } & -0.00 & 0.02 & 0.23 & -0.04 & 0.18 & 2.06 \\
\hline & $(0.01)$ & $(0.01)$ & $(0.07)$ & $(0.04)$ & & \\
\hline \multirow[t]{2}{*}{ Southwest, East } & 0.00 & 0.02 & 0.13 & -0.04 & 0.16 & 2.12 \\
\hline & $(0.01)$ & $(0.02)$ & $(0.05)$ & $(0.03)$ & & \\
\hline \multirow[t]{2}{*}{ South, East } & 0.01 & -0.00 & 0.48 & -0.08 & 0.64 & 2.23 \\
\hline & $(0.00)$ & $(0.02)$ & $(0.05)$ & $(0.05)$ & & \\
\hline
\end{tabular}

Note: Standard errors are in parentheses.

the profiles of the north and midlands. Both exhibit a steep ascent from the mid-1860s to the late 1870 s followed by a short decline and a plateau in the 1880s. After another sharp increase in the 1890s the profiles are flat until 1912. The other series exhibit fewer changes, reflecting the fact that Wales and the southwest are represented by only two towns each and the south and east only by London. The few changes in these series illustrate the stickiness of trade union wage rates. Despite this there is a close resemblance between the broad pattern exhibited in Wales and the southwest and that of the north and midlands. The clear outlier is London. Only at the very beginning and in the last fifteen years or so of the period does the London wage follow a pattern similar to that of the other regions. Overall the increase in the London wage is less marked than the increase in the wage for the other regions. 


\section{Shillings}

50
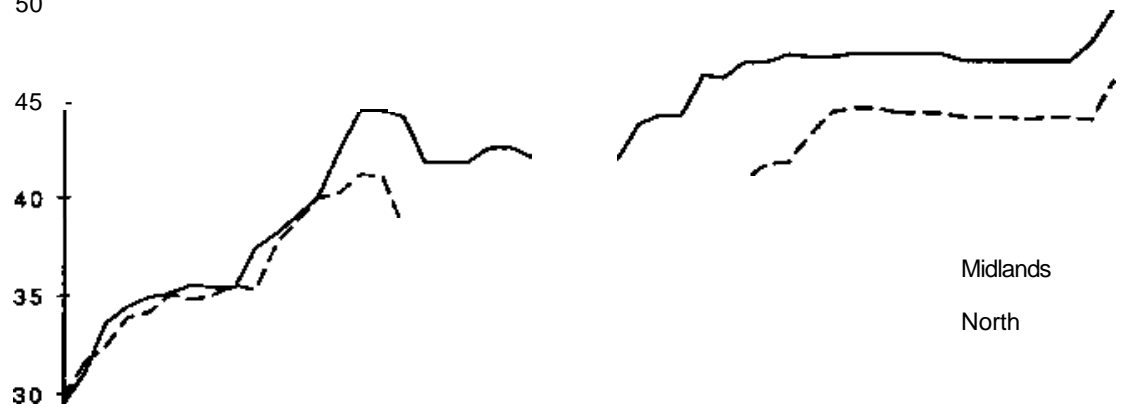

Midlands

North

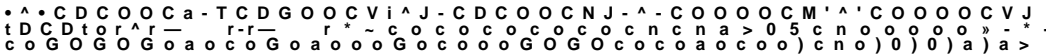

Figure 5.3 Carpenters' wages: midlands and north

Source: See text

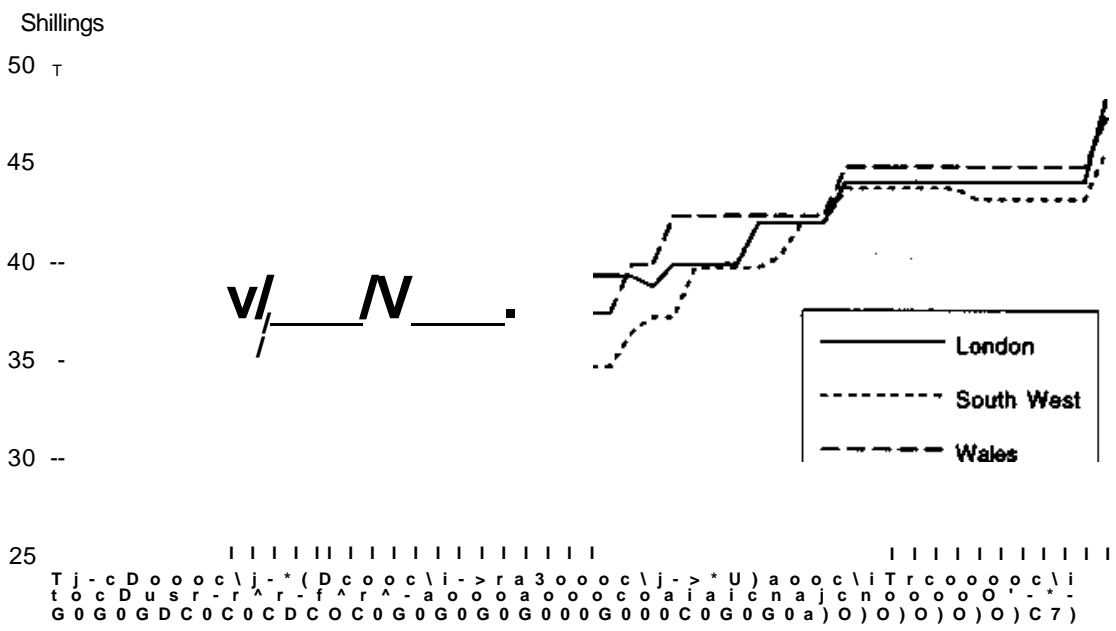

Figure 5.4 Carpenters' wages: London, southwest, and Wales

Source: See text

The results obtained from estimating the error correction model for the ten pairs of regions are presented in Table 5.3. The coefficient on the Alog $W j_{t}$ term is positive and significantly different from zero for all but two of the regional pairs, both of which involved London. The coefficient on the error correction term $\log \left(\mathrm{W}_{/} / \mathrm{W}_{/}\right)_{\mathrm{t}} \mathrm{t}_{\mathrm{t}}$ is negative in each of the regional-pair regressions, and is significantly different from zero in seven of the ten 


\section{REGIONAL LABOUR MARKET INTEGRATION}

Table 5.3 Error correction model for carpenters' wages, 1865-1913

\begin{tabular}{|c|c|c|c|c|c|c|}
\hline Region $i, j$ & Const. & Time $/ 100$ & $\operatorname{Mog} W_{, t}$ & $\log \left(\mathrm{W}^{\wedge} \mathrm{A}-\mathrm{i}\right.$ & $\&$ & $D W$ \\
\hline North, Midlands & $\begin{array}{c}0.16 \\
(0.01)\end{array}$ & $\begin{array}{c}-0.01 \\
(0.02)\end{array}$ & $\begin{array}{c}0.45 \\
(0.14)\end{array}$ & $\begin{array}{c}-0.05 \\
(0.09)\end{array}$ & 0.24 & \\
\hline North, Wales & $\begin{array}{c}0.02 \\
(0.01)\end{array}$ & $\begin{array}{l}-0.05 \\
(0.03)\end{array}$ & $\begin{array}{c}0.38 \\
(0.10)\end{array}$ & $\begin{array}{l}-0.16 \\
(0.11)\end{array}$ & 0.31 & \\
\hline North, Southwest & $\begin{array}{c}0.04 \\
(0.01)\end{array}$ & $\begin{array}{l}-0.07 \\
(0.02)\end{array}$ & $\begin{array}{c}0.66 \\
(0.09)\end{array}$ & $\begin{array}{l}-0.22 \\
(0.08)\end{array}$ & 0.61 & \\
\hline North, London & $\begin{array}{c}0.01 \\
(0.01)\end{array}$ & $\begin{array}{c}0.01 \\
(0.03)\end{array}$ & $\begin{array}{c}0.30 \\
(0.13)\end{array}$ & $\begin{array}{l}-0.16 \\
(0.08)\end{array}$ & 0.23 & \\
\hline Midlands, Wales & $\begin{array}{c}0.06 \\
(0.01)\end{array}$ & $\begin{array}{l}-0.07 \\
(0.01)\end{array}$ & $\begin{array}{c}0.30 \\
(0.08)\end{array}$ & $\begin{array}{l}-0.35 \\
(0.09)\end{array}$ & 0.42 & \\
\hline $\begin{array}{l}\text { Midlands, } \\
\text { Southwest }\end{array}$ & $\begin{array}{c}0.05 \\
(0.01)\end{array}$ & $\begin{array}{l}-0.05 \\
(0.01)\end{array}$ & $\begin{array}{c}0.42 \\
(0.11)\end{array}$ & $\begin{array}{l}-0.16 \\
(0.05)\end{array}$ & 0.42 & \\
\hline Midlands, London & $\begin{array}{c}0.02 \\
(0.01)\end{array}$ & $\begin{array}{l}-0.01 \\
(0.03)\end{array}$ & $\begin{array}{c}0.10 \\
(0.14)\end{array}$ & $\begin{array}{l}-0.12 \\
(0.06)\end{array}$ & 0.20 & \\
\hline Wales, Southwest & $\begin{array}{c}0.03 \\
(0.01)\end{array}$ & $\begin{array}{l}-0.03 \\
(0.03)\end{array}$ & $\begin{array}{c}0.59 \\
(0.17)\end{array}$ & $\begin{array}{l}-0.36 \\
(0.10)\end{array}$ & 0.39 & \\
\hline Wales, London & $\begin{array}{l}-0.02 \\
(0.02)\end{array}$ & $\begin{array}{c}0.07 \\
(0.05)\end{array}$ & $\begin{array}{l}-0.06 \\
(0.20)\end{array}$ & $\begin{array}{l}-0.26 \\
(0.10)\end{array}$ & 0.18 & \\
\hline $\begin{array}{l}\text { Southwest, } \\
\text { London }\end{array}$ & $\begin{array}{l}-0.02 \\
(0.02)\end{array}$ & $\begin{array}{c}0.06 \\
(0.05)\end{array}$ & $\begin{array}{c}0.28 \\
(0.15)\end{array}$ & $\begin{array}{l}-0.18 \\
(0.11)\end{array}$ & 0.12 & \\
\hline
\end{tabular}

Note: Standard errors are in parentheses.

regressions. The regional pairs exhibiting the strongest evidence of integration were Wales and southwest, and midlands and Wales. London, the midlands, Wales, and the southwest each were integrated with three of the four other regions. Surprisingly, the north and midlands were found not to be integrated. The predicted lag between an initial shock to the equilibrium wage ratio and the adjustment back to equilibrium varied from 1.8 years and 1.9 years for the Wales/southwest and midlands/Wales pairs to 7.3 years for the midlands/London pair.

How do the labour markets for carpenters and agricultural labourers compare in terms of regional integration? Although agricultural wage rates appear to have been more volatile than carpenters' wage rates, the tests for regional integration produce results that overall are similar for the two sectors. ${ }^{12}$ The error correction model produces coefficients with similar orders of magnitude in the two sectors, although a larger share of the urban regional pairs were found to be integrated. It is tempting to conclude that urban labour markets were better integrated than rural markets, but the evidence is not compelling. 
GEORGE R. BOYER \& TIMOTHY J. HATTON

Table 5.4 Coefficients of variation of wages of unskilled labourers in five countries, 1860-1910

\begin{tabular}{|c|c|c|c|c|c|c|c|c|}
\hline & \multirow{2}{*}{\multicolumn{2}{|c|}{$\begin{array}{l}\text { England and Wales } \\
\qquad \text { Farm labour }\end{array}$}} & \multicolumn{3}{|c|}{ France } & \multirow{4}{*}{$\begin{array}{l}\text { United } \\
\text { States } \\
\text { Farm } \\
\text { labour } \\
(6)\end{array}$} & \multirow{4}{*}{$\begin{array}{l}\text { Prussia } \\
\text { Unskilled } \\
\text { labour } \\
\text { (7) }\end{array}$} & \multirow{4}{*}{$\begin{array}{c}\text { Sweden } \\
\text { Unskilled } \\
\text { labour } \\
\text { (8) }\end{array}$} \\
\hline & & & \multirow{2}{*}{\multicolumn{2}{|c|}{$\begin{array}{c}\text { Farm } \\
\text { labour }\end{array}$}} & \multirow{3}{*}{$\begin{array}{c}\text { Unskilled } \\
\text { labour } \\
\mathbf{W}\end{array}$} & & & \\
\hline & County & Region & & & & & & \\
\hline & $(V$ & (2) & $(3)$ & W & & & & \\
\hline 1860 & 0.15 & 0.11 & 0.20 & 0.19 & - & - & 0.20 & 0.19 \\
\hline 1870 & 0.15 & 0.12 & - & - & $0 . \overline{23}$ & $0 . \overline{2} 3$ & 0.23 & 0.20 \\
\hline 1880 & 0.16 & 0.12 & 0.18 & 0.17 & 0.22 & 0.16 & 0.22 & 0.22 \\
\hline 1890 & 0.18 & 0.14 & 0.18 & 0.16 & 0.23 & 0.16 & 0.17 & 0.23 \\
\hline 1900 & 0.15 & 0.11 & - & - & - & 0.23 & 0.15 & 0.24 \\
\hline 1910 & - & - & 0.17 & - & 0.18 & 0.15 & 0.17 & 0.20 \\
\hline
\end{tabular}

Sources: Estimates for France in column (3) from Sicsic (1993: 7). Estimates for France in columns (4) and (5) from Weir (1991: 12). Estimates for the United States from Roberts (1990: 18). Estimates for Prussia and Sweden from Soderberg (1985: 276).

Notes: The estimates for France, Prussia, and Sweden are at the departmental/county level of aggregation. The estimates for the United States are at the regional level. Estimates for both the county and regional level are reported for England and Wales. The estimates for France are for the years 1862, 1872, 1882, 1892, 1912.

\section{IMPLICATIONS OF THE TEST RESULTS}

In this section we further analyse the results obtained in the preceding sections. First, we compare the extent of labour market integration in England and Wales with that of other industrializing countries in the late nineteenth century. Second, we use the results of the error correction model to determine the extent of labour market integration between regions within England and Wales. We then compare our conclusions with the results of the literature on inter-regional migration.

In Table 5.4 our estimates of the coefficient of variation of agricultural labourers' wages from 1860 to 1900 are compared with estimates for the United States, France, Prussia, and Sweden. The reported coefficients of variation for France, Prussia, and Sweden are for wages of agricultural labourers and general unskilled labourers at the departmental/county level of aggregation, while those for the United States are for wages of agricultural labourers at the regional level. Thus the estimates for the United States correspond to the regional estimates for England and Wales, while the estimates for France, Prussia, and Sweden correspond to the county estimates for England and Wales.

Three results stand out in Table 5.4. First, from 1860 to 1880 the market for unskilled labour was better integrated in England and Wales than in the other economies. ${ }^{13}$ Given that Britain began to industrialize several decades before the other countries and was by any measure the most developed economy at least until the 1890 s, this result supports the hypothesis that 


\section{REGIONAL LABOUR MARKET INTEGRATION}

improvements in transportation and information networks during economic development play a major role in increasing labour market integration. Second, the two most rapidly industrializing economies during the period, the United States and Prussia, experienced wage convergence in their unskilled labour markets in the late nineteenth century, while England and Wales did not. Again, this suggests that economic development leads to increased labour market integration. Conversely, it is possible that regional wage convergence was a cause of rapid economic growth in the United States and Prussia. Third, wage dispersion in England and Wales was significantly higher in 1890 than in the other years. The sharp increase in wage dispersion from 1880 to 1890 and its sharp decline from 1890 to 1900 were largely the result of movements in wages in the lowest wage region, the east, and the highest wage region, the north. From 1880 to 1890 , nominal wages declined by 9.1 per cent in the east and increased by 2.3 per cent in the north, while from 1890 to 1900 wages increased by 20 per cent in the east and by 5.3 per cent in the north. ${ }^{14}$ The ratio of wages in the north to wages in the east increased from 1.39 in 1880 to 1.56 in 1890 , and then declined to 1.37 in 1900.

Turning to regional integration within England and Wales, the results obtained from the error correction model indicate that many regional pairs' labour markets at best were only weakly integrated. For each regional pair there was some tendency for wage ratios, once disturbed, to revert to a longrun stable path. However, the small size and lack of statistical significance of many of the coefficients on the $\log \left(\mathrm{W}_{\mathrm{z}}-\mathrm{W}_{;}-\right)_{\mathrm{r}}$ - i term show that this often was a slow process.

Some regions seem to have been better integrated than others. In agriculture, the north, midlands, south, and Wales were well integrated with other regions, while the southwest and east were poorly integrated. The results of the error correction model suggest that the southwest was integrated only with Wales. This finding is consistent with the literature on migration. Baines (1985: 234) found that the southwestern counties of Devon, Cornwall, and Somerset had relatively low rates of internal migration. ${ }^{15}$ The major destination of out-migrants, especially in the 1870 s and 1880 s, was South Wales (Friedlander and Roshier 1966: 254-6, 263). The Royal Commission on Labour (1893) reported that

[farm] labourers from Wiltshire, Somerset and Devon, from Hereford and the Cirencester district of Gloucestershire have almost everywhere superseded the indigenous Welsh labourer in the Vale of Glamorgan. . . . But even the newcomers do not remain very long on the land, . . . so that other labourers have to be continually drafted from the same English counties to replace them.

(quoted in Thomas 1969: 45-6)

The east's lack of integration with other regions is harder to explain, 
although Baines (1985: 234-5) found that Norfolk and Suffolk had relatively low out-migration rates, and Frederick Clifford (1875: 124-5) wrote that East Anglian farm labourers 'are far too slow in migrating . . . even when there is a reasonable assurance of higher wages'. Easterners who did migrate overwhelmingly moved in the direction of London, which for most of them could be reached without passing through another region (Friedlander and Roshier 1966: 252-8). ${ }^{16}$

Turning to the carpenters, the results of the error correction model suggest that each of the regions was reasonably well integrated with the others. London's wage profile looks different from the wage profiles of the other regions. However, although the short-run correlations between wage changes in London and other regions are low, in the long run London appears to be integrated with every region except the southwest.

The regressions of the coefficients of variation on a time trend reported in Table 5.1 show that regional wage dispersion for agricultural labourers increased during the second half of the nineteenth century. Is this result consistent with the migration literature? Recent estimates by Baines (1985: 238) suggest that the rate of male internal migration from thirty-four rural British counties declined from 10.9 per cent of the 'total native population' in 1871-80 to 9.3 per cent in 1881-90 and further to 8.9 per cent in 1891-1900. The rate of male internal migration declined sharply in the 1880s in all five eastern counties and in the southwestern counties of Devon, Cornwall, and Somerset (Baines 1985: 287-90). Baines (1985: 241) concluded that the decline in rural out-migration in the 1880s and 1890s 'must have been caused by changes in the relative attractiveness of towns ... [perhaps] by fluctuations in the demand for building labour'. However, rural-urban wage differentials were larger in the 1880s and 1890s than in the 1870s (Boyer and Hatton 1994: 21-2; Williamson 1985: 49). Moreover, Boyer's (1986) analysis of migration from twenty rural southern counties to six major destinations in each decade 1851-60 to 1891-1900 found that the rate of migration declined significantly in the 1880s and 1890s even when one controlled for origin and destination wage rates and the proportion of the rural population who were young adults.

On the other hand, migration rates in the second half of the nineteenth century were higher than English migration rates in the 1920s and 1950s or migration rates in current Third World countries (Hunt 1973: 262; Williamson 1988: 291-3). From 1841 to 1911, 4.5 million persons migrated from rural registration districts in England and Wales (Cairncross 1949: 85). Even Norfolk and Suffolk, which had relatively low out-migration rates, experienced a loss of 373,000 migrants from 1851 to 1900 (Cairncross 1949: 84). In sum, England and Wales experienced a high rate of labour migration in the second half of the nineteenth century, but our results show that it was not high enough to ensure that labour markets were arbitraged in the short run. 


\section{REGIONAL LABOUR MARKET INTEGRATION}

\section{CONCLUSIONS}

The only previous empirical analysis of market integration in England and Wales, by E.H. Hunt (1973, 1986), concluded that both rural and urban regional wage differentials declined significantly in the second half of the nineteenth century. Our results indicate that the issue of market integration is much more complex than Hunt's analysis suggests. Statistical tests for trends in the coefficient of variation of wages show that regional wage differentials for carpenters declined in the second half of the nineteenth century, but regional differentials for agricultural labourers increased.

We also divided England and Wales into six regions and examined the degree of market integration between each pair of regions using a simple error correction model. The results of these tests suggest that some regions were better integrated than others. In particular, the agricultural labour markets in the southwest and the east were very poorly integrated with labour markets in other regions. Although there is some evidence that the labour market for carpenters was better integrated than that for farm labourers, some regional pairs' labour markets were weakly integrated at best. Overall, the results support the conclusion of Clapham (1938), Rowe (1926), and many contemporaries that the integration of labour markets at the national level was far from complete in 1914.

\section{APPENDIX}

In this appendix we develop a simple model of labour demand, labour supply, and wage rates where two labour markets are linked together and also to third markets by migration. From this analysis we obtain the error correction model used in estimation and which appears as equation (5.2) in the text.

In the two labour markets, $i$ and; respectively, labour demands are

$$
\log 1 £=\text { aflog } \mathrm{W}^{*}+D_{k}, \quad \log \mathrm{ly} ?=\operatorname{aylog} \mathrm{W},+D_{j t}
$$

where $\mathrm{W}_{,}, W j$ are nominal wages and all other factors (e.g. output prices) are in the demand shift terms $D_{t}, D j$. Changes in labour supply are simply the difference between rates of natural increase, $n$, and rates of net outmigration, $m$, so that

$$
\text { Alogli? }=5^{\wedge} \sim m_{i t}, \quad \operatorname{Alog} \mathrm{I}_{;} \mid=n_{j t}-m_{j t}
$$

Rates of out-migration are determined by the (geometric) weighted average of the wage rate in the other region ( $i$ or; ) and in the third market, $\mathrm{z}$, relative to that in the own market:

$$
\begin{aligned}
& \left.m_{n}=\mathrm{ftfc}-\log \mathrm{Wy},-,+\left(1-s_{i}\right) \log \mathrm{W}^{*}-!-\log \mathrm{W}^{*}-!+k_{u}\right] \\
& \left.m_{j t}=\mathrm{p}^{\wedge} \mathrm{sylog} \mathrm{W}_{-}^{*_{-}},+(1-s j) \log \mathrm{W}_{2 \mathrm{f} \_} \mathrm{t}-\log \mathrm{W}_{;},_{-1}+k_{j t}\right]
\end{aligned}
$$


where $5, S j$ represent the 'weight' of the third market immigration decisions in $i$ and /, and $\&$, and $k j$ represent the non-wage advantages of location $i$ and $j$ relative to the weighted average of the others.

Converting the labour demand equations to changes and setting $\mathrm{A} \log \mathrm{Z}, ?=\mathrm{A} \log \mathrm{Z} . *$ for both markets gives

$$
\begin{aligned}
& m_{i t}=n_{l t}-01,-\mathrm{Alog} \mathrm{Wrt}-A D_{t t} \\
& m_{j} t=n_{j t}-\mathrm{o} / \mathrm{A} \log \mathrm{Wy},-A D_{j t}
\end{aligned}
$$

Using equations (5A.3) and (5A.4) to eliminate $m$, we obtain

$$
\mathrm{A} \log \mathrm{W}^{*}=\underset{\mathbf{U}_{2^{\prime}}}{\wedge}-\wedge_{\mathbf{U}_{\mathbf{z}}}^{\wedge} i-\underset{(\mathbf{X j}}{h}\left[s f c_{\%} W_{j t-x}+(1-5 /) \log \mathrm{W}_{2,-1}-\log \mathrm{Wa}-\mathrm{t}+k_{l t}\right]
$$

$\mathrm{A} \log \mathrm{W}_{\mathrm{yt}}=\underset{\mathrm{v}}{\%}-\hat{\mathrm{y}}_{\mathrm{y}}-{\underset{\mathrm{u}}{;}}_{;}\left[M^{w} *_{-i}+\left(\mathrm{i}-\wedge \log \mathrm{W} \ll-!-\log \mathrm{Wy},-.,+*_{\mathrm{y}} \mathrm{J}\right.\right.$

Finally, ehminating $\mathrm{W}_{\mathrm{zf}-\mathrm{t}}$ by combining the two expressions in (5A.5) gives the following:

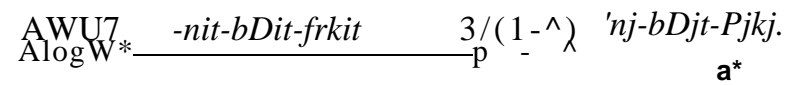

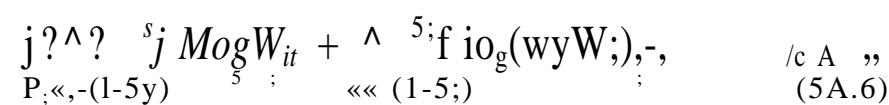

Equation (5A.6) is essentially the equation we use for estimation in the text. The terms in $A D$ reflect demand conditions which we do not have in our estimating equation. If the variables driving labour demand are integrated of order 1 (as is frequently found with price series) then $A D$ will be integrated of order 0 and will form a random disturbance. In the estimating equation, the variables $n$ and $k$ are treated as constants, although any secular changes will be captured in the time trend which is added to the model. The coefficient on $A \log \mathrm{W}^{\wedge}$ is expected to be positive and would be close to one for two symmetric regions. The coefficient on $\log \left(\mathrm{W}_{\mathrm{z}} / \mathrm{W}_{/}\right)_{\mathrm{t}_{-1}}$ will be negative since a, the labour demand elasticity, is expected to be negative. It is worth noting that the lower the migration elasticity, (3; which reflects the degree of labour mobility, the smaller will be the coefficient on the error correction term in the equation.

\section{NOTES}

We would like to thank George Grantham, Mary MacKinnon, Joel Mokyr, Jeffrey Williamson, and conference participants for helpful comments on an earlier version of this paper.

1 The literature on migration in Victorian Britain includes Redford (1926), Cairncross (1949), Thomas (1954, 1972), Friedlander and Roshier (1966), Baines (1985), and Boyer (1986). 


\section{REGIONAL LABOUR MARKET INTEGRATION}

2 The coefficient of variation of wages is defined as the standard deviation of wages divided by the mean wage. Hunt refers to the coefficient of variation as the 'standard deviation of county earnings from their mean' (1973: 59). In his 1986 paper, Hunt (1986: 951) calculates the coefficient of variation of agricultural labourers' weekly earnings across forty-two English counties in 1767-70, 1794-5, 1833-45, 1867-70, and 1898.

3 According to Rowe (1928: 65-6), 'all employers [in the building trades] had to pay the same rate, not mainly as a result of trade union organisation, but owing to the peculiar economic conditions of employment in their industry. . . . [Because] all ordinary building operations are much alike, there is therefore a great potential fluidity of labour between different firms in any district.'

4 Hunt (1973: 8) divided England and Wales into ten districts. The major differences between our regional breakdown and Hunt's is that Hunt divides Wales into two regions and the north into four regions, while we consider Wales and the north each to be one region. In addition, Hunt includes a region, London and Home Counties, that we do not, and we include a region, east, that Hunt does not.

5 Because Hunt $(1973,1986)$ examines the coefficient of variation of wages for only a few benchmark years, he is unable to separate trends in wage dispersion from temporary shocks.

6 For instance, Hodne and Gjolberg (1981) use correlation coefficients to analyse labour market integration in nineteenth century Norway.

7 Thus, this approach combines short-run correlation of changes in wages and long-run cointegration.

8 Hunt (1973: 80-7) found that food prices were similar throughout rural England, that rural rents were slightly higher in the north than in the south, and that coal prices were higher in the south than in the north. Hunt's findings are supported for an earlier period by Crafts (1982: 68), who found that in 1843 regional price variations were relatively small even when urban areas were included.

9 The major reason for the high cost of living in London was its relatively high cost of housing. The Board of Trade report (1908b: xvi) found that 'the average rents in the towns included in the enquiry are from 50 to 60 per cent of those prevailing in London'. Overall, the report found that the cost of living was higher in London than in any other British city. Examples of the relative cost of living in several of the cities and towns for which we have wage data are: London $=100$; Newcastle $=94 ;$ Cardiff $=91 ;$ Leeds $=86 ;$ Manchester $=86 ;$ Birmingham $=85$; Stockport $=81$.

10 Hunt's conclusion was based on a comparison of the coefficient of variation of weekly earnings across counties in 1867-70 and 1898. For our sample of seventynine farms, the coefficient of variation of weekly wages increased from 0.157 to 0.165 from 1867-70 to 1898. Hunt obtained earnings data for 1867-70 from Bowley (1900a: end table) and for 1898 from Board of Trade (1900: 28-9, 58, 73 4). These sources report weekly wage rates of agricultural labourers as well as weekly earnings. The coefficient of variation of weekly wages across counties calculated using these data is equal to 0.163 in $1867-70$ and 0.136 in 1898 . Bowley (1898: 704-7, 1900a: end table) also reports county-level wage data for earlier years, including 'the returns of agricultural wages collected officially for Michaelmas and Christmas, 1860, and Lady Day, 1861'. From these data we calculate that the coefficient of variation of weekly wages across counties in 1860-1 was equal to 0.131 . Thus, the county-level wage data reported by Bowley and Fox suggest that wage dispersion did not decline, and might have increased slightly, from $1860-1$ to 1898 . 


\section{GEORGE R. BOYER \& TIMOTHY J. HATTON}

11 The one exception is the east, the most arable region in Britain. The coefficients on the Alog $\mathrm{W} / \mathrm{f}$ term are significantly larger in the south/east and midlands/east regressions than in the other regressions involving the east.

12 The apparent differences in volatility may be due in part to differences in the nature of the wage data, although it seems likely that urban wages were indeed more sticky than rural wages.

13 The unskilled labour market also might have been better integrated in England and Wales than in the other countries in 1890 and 1900. Weir's estimates suggest that the county-level variation in agricultural labourers' wages in 1890 was lower in France than in England and Wales, but the estimates by Sicsic suggest that wage dispersion in France was equal to that in England and Wales. Moreover, the coefficient of variation of wages for French unskilled labour was higher than that for English and Welsh agricultural labour in 1890. The estimates in Table 5.4 also suggest that wage dispersion was lower in Prussia than in England and Wales in 1890, and that wage dispersion was about the same in the two economies in 1900. However, Prussia is only one region within Germany, and there is reason to believe that the Prussian estimates understate the extent of wage dispersion across German regions. Bry (1960: 106) maintained that there were 'striking differences in wages paid in the several geographic regions of Germany' in 1885 and 1905.

14 For England and Wales as a whole, nominal wages of agricultural labourers declined by 0.4 per cent from 1880 to 1890 , and increased by 9.6 per cent from 1890 to 1900.

15 On the other hand, each of these counties had 'exceptional' emigration rates (Baines 1985: 234).

16 The fact that the intervening counties between the migrants' place of origin and London were in the east suggests that easterners might have had a high rate of intra-regional migration but a low rate of inter-regional migration. For evidence that this was the case, see Ravenstein (1885: 206-11). 